\title{
A Study of Subject Service in Chinese Academic Libraries
}

\author{
Hui $\mathrm{HaO}^{1, \mathrm{a}}$, Yongfeng Wang ${ }^{2, \mathrm{~b}}, \mathrm{Na} \mathrm{Li}^{3, \mathrm{c}}$ and Junqiang Yang ${ }^{4, \mathrm{~d}}$ \\ ${ }^{1}$ Institute of NBC Defense, Changping District, Beijing City, 102205, China \\ ${ }^{2}$ Institute of NBC Defense, Changping District, Beijing City, 102205, China \\ ${ }^{3}$ Institute of NBC Defense, Changping District, Beijing City, 102205, China \\ ${ }^{4}$ Institute of NBC Defense, Changping District, Beijing City, 102205, China \\ aemail:798771780@qq.com, ${ }^{b}$ email: fhlib@sina.com, ${ }^{\mathrm{c} e m a i l: ~ f h l i b @ s i n a . c o m, ~}$ \\ demail:273165445@qq.com
}

Keywords: Subject Service; Academic Library; Subject Librarians; Service Models

\begin{abstract}
Subject service provides the academic libraries opportunities to enhance core competiveness and realize sustainable development. It is a prerequisite to create a supportive external environment to guarantee its sound development. And what is more important is to promote library's internal construction through librarian training, service model selection and latest technology application to implement high-quality subject service.
\end{abstract}

\section{Introduction}

The history of subject service can be traced back to the 1950s when some academic libraries in the United States and Great Britain first brought this model of service delivery into practice. In 1998, the Tsinghai University library introduced subject service into China and a number of university and college libraries followed its steps. Today, there are more than one hundred academic libraries in China having established subject service system [1]. In recent years, a number of articles were published in the library literature that pertained to subject service. This paper will analyze the present condition of subject service and explore how to implement high-quality subject service according to Chinese academic library characteristics.

\section{Necessity of Subject Service}

\section{Users' Changed Demands for Library}

Academic libraries have been playing an important role in supporting the university's teaching and research with its resource advantage. And it was major access to information and academic resources for students, faculty and staff. However, with the ubiquity of computer use and growing popularity of the Web, easy accessibility and richness of information on line has greatly affected traditional library services. The vast majority of the resources the user needs, or thinks he/she needs, are now available online [2]. Reducing gatecounts and reference statistics reflects the fact that fewer people were walking in the doors of the library and asking for help. Meanwhile, facing astonishing amount of information, users often feel lost with difficulties to acquire expected materials accurately and effectively. Increased accessibility via technology has meant increased complexity of information retrieval $[3,4]$. Users were "increasingly expecting everything to happen online but finding that in practice, the more online access they have, the more help from a qualified professional they need to navigate it”, a point made by Nyamboga, Brown et al. and Fullerton and Leckie [3-5].It is not that the users do not need library any more, but that traditional library service no longer meets the changed needs of users. In this context, "libraries must find new capacity from within their existing resources" [6], taking innovations and exploiting new service mode. More advanced service model, sort of knowledge service which is based on the information search, management, analysis and reconstruction and embedded into the user's problem solving process to offer creative solutions is badly needed. 


\section{Subject Construction Demands}

Subject construction is essential to university development, as university is an academic institution built upon subjects and a variety of its functions and activities are subject-centered. Subject construction is the fundamental for university, involving every aspect the university. It is not only libraries' responsibilities but also its way to enhance core competiveness to provide information support and all-round knowledge service for the university's subject construction.

\section{Status quo of Subject Service}

A large number of universities in China have established subject service system but few of them are capable of offering high-quality service. Some academic libraries provide kind of improved traditional library service in the name of subject service or set subject librarian positions but cannot fully satisfy the users' demands. According to a survey of 62 librarians coming from 34 university libraries located in different regions of China participating in Project 985 (a project for funding world-class universities in the 21st century conducted by the government of the People's Republic of China), 65 percent of the librarians have less than two years work experience in subject services, despite the fact 69 percent of them are subject liaisons. These statistics show that even in Project 985 university libraries, subject service is still in the exploratory stage and the capacity of subject librarians and service quality need to be improved [7].

\section{Address Challenges and Seize Opportunities}

The subject service system in Chinese academic libraries is far from mature, facing a lot of barriers and difficulties, however, it is the future of library, offering great chances for it to realize service mode transition and sustainable development. The academic libraries should grasp this opportunity to push forwards subject service into a new stage with both external and internal endeavors.

\section{Create Supportive External Environment}

Subject service is a comprehensive system, with university administration, library and departments closely integrated. A sound supportive and collaborative relationship among these parties is a prerequisite to subject service development.

\section{Get Support from University Administration}

University administration's attitude is a significant factor to influence the effectiveness and effects of subject service. The library should make efforts to get support from university administration, making subject service part of the university's overall planning. With such top-level design, library can expect to get sufficient backing in terms of human recourses, funding, rewards policies and logistics etc.

Library needs to make every endeavor to get support from the university and the best way to get advocacy is to demonstrate relevance and value to the institution. For instance, some academic libraries present Annual Influence Report for major subjects of the university or craft data management plans for the grant proposals, attracting attention from university administration and in turn get more support for library and subject service construction, creating a positive circle.

\section{Collaborate with Management Departments}

Subject service cannot be carried out smoothly without the support from management departments. Establishing collaborative relationship with other sectors of the university such as research department, information department and logistics department etc. helps to promote its efficiency and performance. For example, through collaboration with the research department, library is integrated in academic achievement certification program, responsible for providing publication proof for students, faculty and staff. Library takes advantage of its expertise and its service is welcome by its clients. At the same time, the library implements original documents collection development and learns the present condition and future trend of the subject development of the university. What is more important, it offers opportunities for subject librarians to get closer contact with researchers and learn better about their projects, which sets sound foundation for further personalized and embedded subject service. 


\section{Library Internal Construction}

With supportive external environment, the most essential part is to promote the internal construction of the library.

\section{Subject Librarian Cultivation and Stimulation}

Subject services are provided by subject librarians whose librarianship knowledge, subject expertise and personal qualities influence service standard to a great extent.

\section{Subject Librarian Selection and Training}

In the United States and Great Britain academic libraries, most subject librarians have master degrees of librarianship with appropriate subject background and many of them possess doctor degrees of related subject. In comparison, both the qualification requirements of the occupation and the subject service content in China's university libraries are "left behind." For a long time librarian had been considered a position that could be held by anyone and a lot of librarians did not have strong academic background. In recent years, this condition has changed a lot, a large number of graduates and postgraduates choose being a librarian as their careers, which sets a talent foundation for the libraries to conduct subject service. However, many academic librarians in China still do not have librarianship education or librarian information literacy training, and hybrid librarians who possess librarianship knowledge as well as subject expertise are few and far between.

In this context, library is expected to push forwards more attractive and advantageous recruitment policies to absorb hybrid talents into the subject librarian team. And at the same time, selecting excellent librarians from current employees and cultivating them to qualified subject librarians through motivation and training is a more practical way. A subject librarian's responsibilities include reference work, information organization and management, collection development, information literacy education, liaison with academic departments and provision of embedded service for faculty and staff to support their research etc. Thus, library and information science expertise still plays a fundamental role to be a successful subject librarian; Librarians with specific subject knowledge are preferred; Proficiency of a foreign language could be much of help when it comes to providing high standard subject service. Personal attributes such as enthusiasm, initiative, flair, interpersonal skills are attached increasing importance to being a successful subject librarian. So library is supposed to take these qualities into consideration and make comprehensive assessment to select most suitable people and foster them to subject librarians.

Having chosen suitable subject Liberian candidates, library needs to provide proper platform and opportunities to elevate their career development. Library can encourage librarians to participate in on-the-job training and continuing education courses to further their library science skills and particular discipline expertise, attend academic conference to learn the latest trends in the area and exchange experience with peer librarians and invite experts to give lectures to promote librarians' competency. Lack of subject expertise is a major problem hindering Chinese academic librarian to provide satisfactory service. Librarians with at least some subject knowledge will benefit by having the capability to provide further embedded service in research projects. Subject librarians are generally able speak the same language as researchers in their subject. Not only does this improve communication because all parties are on the same page, but it also allows the subject librarian to build the trust necessary to become an integrated part of the research team [8]. Besides the measures such as on-the-job training and continuing education courses mentioned before, most effective way for subject librarians to accumulate subject knowledge is to be embedded in department research programs. Subject librarians can develop personal touch with faculty and staff of a teaching or research department, "attend departmental seminars and social events; perform periodic literature searches on their faculty's publications; keep track of their students' dissertations; read faculty and unit Web pages, unit newsletters and other promotional materials; and attend faculty meetings" [9].

\section{Advantageous Policy to Stimulate and Protect initiative}

Subject service requires librarians to devote a lot of time and energy. And committing time and effort to it can be risky. Relationships can take longer to evolve and significant payoffs may be years off instead of months. In the process of conducting subject service, especially in the initial 
stages, academic librarians may encounter a lot of difficulties. This requires subject librarians to have passion for his/her work and strong professional responsibilities. What is more important is that the library should set up advantageous policies to support subject librarians' work, stimulating and protecting their initiative. Library need to take measures to help subject librarians to balance workload, acknowledge the added value they bring into the service and set policy to advocate their time and energy commitment in terms of rewards and promotion.

\section{Select Suitable Service Model}

Currently, the most popular subject service mode in China is the "subject librarian-liaison professor" model. On one hand, library arranges subject librarian in charge of subject service of one or more departments. On the other hand library invites a senior teacher or a leader of the department who knows well of current condition and trends of the department research as liaison. The liaison professor offers subject librarian information concerning subject construction, research programs, changing conditions of disciplines and related demands, which complement subject librarians' shortage in subject expertise. This service model is a result of the relationship between library and department in China. It is a compromise but effective way in the reality that our country's subject service is far from mature and the occupational qualities of librarians are not so satisfactory. There are also some problems in this service model, such as information asymmetry, ineffective communication, push service with little relevance etc. In addition, liaison professors have a lot of teaching and research responsibilities. Library and subject librarians need to think about how to maintain their initiative. At present, most liaison professors participate in these activities as a part-time job, which means it is not an official position, time and endeavor committed to it not easy to be assessed accurately. Library can ask the university administration to set related post, giving advocacy and justification that liaison professors deserve. And the more straightforward and effective way is to promote subject librarian competency and enhance service quality. Once the subject librarians demonstrate liaison professors and their research teams importance and added value they can bring to their teaching and research in terms of reference work, collection development or even crafting data management plans for the grant proposals, maintaining such collaborative relationship would not be difficult.

In recent years, a variety of subject service models come into being, such as the subject group model, subject librarian as part-time academic secretary, subject information sharing space and so on. These new service concepts and modes have respective characteristics and provide solutions to the problem of hybrid talent shortage to some extent.

At present, there is not one service model which is perfect or fully mature. Library should choose suitable mode depending on the subject development, teaching and research structure of the university and condition of the library.

\section{Technological Application to Create Interactive Platform}

Subject service interactive platform is a product of technology development. It allows libraries to conduct subject service more efficiently. It also integrates users into subject service, transforming them from positive receivers into active constructors, which helps to build a user-centered library.

A large number of latest technologies have been exploited to create interactive platform. Libraries can realize instant communication among subject librarian, subject service group, clients and management, with the use of instant messenger; establish blog and subject service Wiki to attract users to take part into subject database construction, which motivates users' interests in participating in subject service and greatly enhances the richness and timeliness of the database; employ information syndication technology to implement services such as information gathering, sharing and pushing; make use of labeling and cataloging technology to realize quick review of subject knowledge; apply web portal technology to integrate functional modules of subject service platform.

The key to a successful subject service platform is to stimulate clients' initiatives and make full use their potentials. Libraries should create the platform from user's perspective to truly meet their needs by taking measures such as enhancing technology application constantly, conducting more active and personalized service and establishing user participation and feedback mechanisms. 


\section{Conclusion}

Like the change from general reference desks to subject librarianship, from functional librarianship to holistic librarianship, this movement may have the momentum to change the way academic librarianship is practiced [2]. The future of the subject service will be very exciting no doubt. This model of service delivery in China's academic libraries is still in the exploratory stage with a variety of problems to overcome. To address these challenges, the library would earn an opportunity to implement service model transcendence and innovation, thus enhancing its core competiveness and realizing sustainable development.

\section{References}

[1] Xuemei Long, Design of subject service models in Chinese academic libraries, Library Development. 2 (2016) 30-33.

[2] Lynne Marie Rudasill, Beyond Subject Specialization: The Creation of Embedded Librarians, Public Services Quarterly. 6(2010) 83-91.

[3] A. Fullerton and G.J. Leckie, Information literacy and higher education, in: Encyclopedia of Library and Information Science, (Vol. 70)(Supp. 3), A. Kent, ed., Marcel Dekker, New York, 2001, pp. 190-205.

[4] C.M.Nyamboga, Information skills and information literacy in Indian university libraries, Program: Electronic Library and Information Systems. 38(4) (2004), 232-239.

[5] C. Brown, T.J. Murphy and M. Nanny, Turning techno-savvy into info-savvy: authentically integrating information literacy into the college curriculum, Journal of Academic Librarianship. 29(6) (2003), 386-398.

[6] R2 Consulting LLC, Consultants in the Library Uh Oh, American Library Association ALCTS Pre-Conference, New Orleans, June 26, 2011. Accessed 20 Dec. 2011.

[7] Jing Guo, Qinling Huang, and Xiaobin Lu, Design and Implementation of a Subject Librarian Training Program for University Libraries in China, Reference \& User Services Quarterly. vol. 54, issue 2, (2014), 43-51.

[8] Jeremy R. Garritano and Jake R. Carlson, A Subject Librarian's Guide to Collaborating on e-Science Projects, Information on http://www.istl.org/09-spring/refereed2.html, 2009.

[9] Tara Tobin Catald, MicMe R. Tennant, and Pamela Sherwill-Namrro, Subject specialization in a liaison librarian program, J Med Libr Assoc 94(2006), 446-448. 